\title{
Ecology and distribution of Lycopodiaceae Mirbel in Malaysia
}

\author{
G. Rusea ${ }^{1}$, K. Claysius ${ }^{1}$, S. Runi ${ }^{1,2}$, U. Joanes ${ }^{2}$, K.M. Haja Maideen ${ }^{3}$, A. Latiff ${ }^{3}$
}

Key words

distribution

ecology

habitats

Lycopodiaceae

\begin{abstract}
This paper is the first account to discuss the distribution, ecology and habitats of the Lycopodiaceae in Malaysia. Lycopodiaceae are widely distributed throughout Malaysia with respect to altitudes and environmental conditions but most abundantly found in hill forest and lower montane forest, terrestrial as well as epiphytic, in shaded or semi-shaded places with relatively high humidity. Pahang in Peninsular Malaysia and Sabah in Borneo have the highest species diversity in terms of the number of species collected.
\end{abstract}

Published on 30 October 2009

\section{INTRODUCTION}

The Lycopodiaceae s.I. are an ancient (Correll 1956) and probably monophyletic family without close living relatives and have a virtually cosmopolitan distribution (Øllgaard 1992). The estimated number of species ranges from approximately 300 to more than 400 around the world (Wikström 2001). It consists of three genera namely Huperzia, Lycopodium and Lycopodiella. Worldwide the estimated number of species for both Lycopodium and Lycopodiella is about 40 (Wikström \& Kenrick 2000b) and the estimated number of species of $\mathrm{Hu}$ perzia is 300 (Wikström \& Kenrick 2000a).

Several Lycopodiaceae (Huperzia carinata, H. phlegmaria, H. serrata, Lycopodiella cernua and Lycopodium clavatum) are listed by Prosea (De Winter \& Amoroso 2003) as containing compounds that may have medicinal value, for $H$. serrata leading to a commercial value of the dried plant product of $1098-2440$ USD per kg (price level 2002). Recently, various media such as television as well as newspapers and magazines have reported that some species in Malaysia are widely collected and sold by local people as a source of income. Information about ecology and distribution of Lycopodiaceae can help to safeguard this family.

\section{METHODS}

Data on ecology and distribution was mostly derived from herbaria sheet information or collection notes and also based on observation during field work. This field work was carried out from October 2001 until December 2002 in various localities in Malaysia. All specimens collected were deposited at the herbarium of the Biology Department, UPM. Lycopodiaceae specimens studied were deposited in various herbaria such as Universiti Kebangsaan Malaysia (UKMB), Universiti Malaya (KLU), Forest Research Institute Centre (KEP), Forest Department Sarawak (SAR), Kinabalu Park (SNP), Forest Department Sandakan (SAN) and Singapore (SING) herbaria.

\footnotetext{
${ }^{1}$ Department of Biology, Faculty of Science, Universiti Putra Malaysia, 43400 UPM Serdang, Selangor, Malaysia.

2 Sarawak Forestry Corporation, Kuching, Sarawak.

${ }^{3}$ Faculty of Science and Technology, Universiti Kebangsaan Malaysia, 43600 UKM Bangi, Selangor, Malaysia.
}

\section{RESULTS AND DISCUSSION}

In Malaysia, the family comprises 32 species including 11 varieties that are found in various altitudes and vegetation types, sometimes in a restricted area (Table 1).

Lycopodiella cernua has the widest distribution in Malaysia and is most common on acid soils and occurs along forest fringes, along roadside, hillsides and mountain slopes followed by Huperzia carinata and $H$. pinifolia, which occur on tree branches.

Lycopodium sp. and $H$. beccarii are only found in Sabah, while $H$. australiana and $L$. volubile are restricted to Cameron Highlands and Sabah. The collection of the latter two species from Gunung Brinchang, Cameron Highlands was made by Abdul Samad, both in the mid 1970s, but nowadays the species is no longer found in that particular area and no recent collection has been reported. According to Chan (2001), the development in Cameron Highlands is a major problem and it is to be feared that these species are now locally extinct. The majority of species are reported from Cameron Highlands, Fraser's Hill and Genting Highlands in Pahang and Mt Kinabalu in Sabah and thus these locations are the most important to the conservation of Lycopodiaceae in Malaysia.

\section{Diversity of habitat and growth form}

Habitats of these fern-allies vary from terrestrial to epiphytic or lithophytic with long creeping or climbing shoots. Epiphytic Lycopodiaceae are pendulous with dichotomous branching and grow at heights of about $1 \mathrm{~m}$ up to $10 \mathrm{~m}$ from the ground. The epiphytic habit is most common in the genus Huperzia. The creeping habit is seen in Lycopodium, e.g., in L. clavatum and $L$. platyrhizoma (sometimes regarded as a variety of $L$. clavatum), while $L$. casuarinoides and $L$. volubile are climbing or scrambling. In Lycopodiella cernua the main stem is creeping while the branches are erect and sometimes climbing.

In Malaysia, Lycopodiaceae are found in various forest types but mostly in hill forest and lower montane forest, often in shaded or semi-shaded places with high humidity and cool environment. Most $L y c o p o d i a c e a e$ require high moisture to thrive. In lowland mixed dipterocarp forest, Lycopodiaceae are often encountered near streams or rivers as epiphytes on mossy tree trunks. The permanent moisture in these habitats allows them to survive relatively long periods of drought. Some species can be found in open places such as Lycopodiella cernua, which is a sun loving plant needing little water for survival. 
Table 1 Distribution of Lycopodiaceae species in Malaysia. Abbreviations used: $\mathrm{Pn}=\mathrm{P} . \mathrm{Pinang}, \mathrm{KI}=\mathrm{Kelantan}, \mathrm{Tg}=\mathrm{Terengganu}, \mathrm{Pk}=\mathrm{Perak}, \mathrm{Ph}=\mathrm{Pahang}$, $\mathrm{SI}=$ Selangor, $\mathrm{Ns}=\mathrm{N}$. Sembilan, $\mathrm{Ml}=$ Melaka, $\mathrm{Jh}=$ Johor, $\mathrm{Ps}=$ Perlis, Kd = Kedah, Sab = Sabah, Sar = Sarawak.

\begin{tabular}{|c|c|c|c|c|c|c|c|c|c|c|c|c|c|}
\hline Species & Pn & $\mathrm{KI}$ & $\operatorname{Tg}$ & $\mathrm{Pk}$ & $\mathrm{Ph}$ & SI & Ns & $\mathrm{Ml}$ & Jh & Ps & $\mathrm{Kd}$ & Sab & Sar \\
\hline Huperzia australiana (Herter) Holub & & & & & + & & & & & & & + & \\
\hline Huperzia beccarii (Alderw.) Holub & & & & & & & & & & & & + & \\
\hline Huperzia carinata (Desv. ex Poir.) Trevis. & + & + & + & + & + & & & + & & + & & + & + \\
\hline Huperzia dalhousiana (Spring) Trevis. & + & & & + & + & & & & + & & & + & + \\
\hline Huperzia goliathensis (Alderw.) Holub & & & & & + & & & & & & & + & \\
\hline Huperzia nummulariifolia (Blume) Jermy & & & & + & + & + & & & + & & + & + & + \\
\hline Huperzia phlegmaria (L.) Rothm. & & & & + & + & & & & + & & & + & + \\
\hline Huperzia phlegmaria var. brachystachyum Rosenst. & & & & & + & + & & + & + & & & + & + \\
\hline Huperzia phlegmaria var. filiforme Alderw. & & + & & + & + & & & & + & & + & + & \\
\hline Huperzia phlegmaria var. latifolium Alderw. & & & & + & + & + & + & & & & & + & \\
\hline Huperzia phlegmaria var. laxum Blume & + & & & + & + & & & & + & & + & & \\
\hline Huperzia phlegmaria var. longifolium Spring & & & & & + & & & + & & & + & & \\
\hline Huperzia phlegmaria var. ovatum Alderw. & + & & & + & + & & & & + & & + & + & + \\
\hline Huperzia phlegmarioides (Gaudich.) Rothm. & & & & + & + & & & & & + & + & & \\
\hline Huperzia phyllantha (Hook. \& Arn.) Holub & + & + & & & + & + & & & & & & & \\
\hline Huperzia pinifolia Trevis. & & + & & + & + & + & & + & + & & & + & + \\
\hline Huperzia prolifera (Blume) Trevis. & & & & + & + & & & & & & & + & \\
\hline Huperzia serrata (Thunb. ex Murray) Trevis. & & & & + & + & & & & & & & + & \\
\hline Huperzia squarrosa (G.Forst.) Trevis. & + & + & & & + & & & & + & & & + & + \\
\hline Huperzia tetrasticha (Kunze) Holub & & & & & + & & + & & & & & + & + \\
\hline Huperzia verticillata (L.f.) Trevis. & & & & & + & + & & & & & & + & + \\
\hline Lycopodium casuarinoides Spring & & & + & + & + & + & & & + & & + & + & \\
\hline Lycopodium clavatum (L.) P.Beauv. & & & & & + & & & & & & + & + & \\
\hline Lycopodium clavatum var. divaricatum Racib. & & & & & + & & & & & & + & + & \\
\hline Lycopodium platyrhizoma J.H.Wilce & & & & + & + & & & & & & + & + & \\
\hline Lycopodium sp. & & & & & & & & & & & & + & \\
\hline Lycopodium volubile G.Forst. & & & & & + & & & & & & & + & \\
\hline Lycopodiella cernua (L.) Pic.Serm. & & + & & + & + & + & + & + & + & & & + & + \\
\hline Lycopodiella cernua var. capillaceum Spring & & & + & + & + & + & & + & + & & & + & \\
\hline Lycopodiella cernua var. crassifolium Spring & & & & + & + & & + & & + & & + & + & \\
\hline Lycopodiella cernua var. pendulum Baker & & & + & & + & + & + & & & & + & + & + \\
\hline Lycopodiella cernua var. salakense Alderw. & & & & + & + & + & + & & & & & + & \\
\hline
\end{tabular}

Species recorded from upper montane forest were found only in Mt Kinabalu, the highest mountain in South East Asia between the Himalayas and New Guinea, and the only location of upper montane forest in Malaysia. This is the only location where, at $3000 \mathrm{~m}$, we found a specimen that is possibly representing a new, endemic species. Huperzia beccarii is found here at about $2100 \mathrm{~m}$, a species also reported from the Philippines, Sumatra and China.

The distribution of the Lycopodiaceae can be tabulated under five vegetation types, although single species may occur in different types (Fig. 1):

1. Lowland mixed dipterocarp forest (LMDF), 100-700 m.

2. Hill forest (HF), 700-1200 m.

3. Lower montane forest (LMF), 1200-2600 m.

4. Upper montane forest (UMF), 2600-3500 m.

5. Limestone forest (LF).

Species numbers are higher in hill and lower montane forest than any other vegetation type. Twenty-six species including 11 varieties and 26 species with 9 varieties, respectively, were reported.

\section{Lowland Mixed Dipterocarp Forest (LMDF)}

In Malaysia, most of the forest is categorized as lowland mixed dipterocarp forest which is found at the lowest levels on the mountain (Parris 1997) and often characterized by peaty or alluvial soil. In Malaysia, 14 species of Lycopodiaceae including eight varieties were recorded from this forest type. They are mostly found as epiphytes on tree trunks and often near rivers or streams in shady places or creeping in open sunny places in the case of the genus Lycopodiella.

\section{Hill Forest}

Hill forest is a zone that grades into lower montane forest at its upper limits. The soil type varies from clay to loam soil but is occasionally peaty. The Huperzia-species found here occur mainly epiphytic on trees or rocks while Lycopodium- and Lycopodiella-species are creeping in semi-shaded or open places. Lycopodiella cernua var. salakense is restricted to this forest type.

\section{Lower Montane Forest}

Lower montane forest is also called oak-laurel forest because of the preponderance of members of the oak family (Fagaceae), e.g. Lithocarpus, Quercus, and the laurel family (Lauraceae) (Parris 1997, Kiew 1998). In some areas like Mt Kinabalu, it ranges from 1200 to $2600 \mathrm{~m}$. The floristic composition of Lycopodiaceae in this vegetation type is diverse, and all genera occur here. Many Huperzia-species are found here, which are often terrestrial and often produce bulbils for vegetative reproduction.

\section{Upper Montane Forest}

Upper montane forest is characterized by the presence of podocarps, Rhododendron species and Leptospermum recurvum (Parris 1997), and Dacrydium species in some areas (Kiew 1998). This forest type contains only three species of Lycopodiaceae ( $H$. australiana, L. platyrhizoma and Lycopodium sp.). These species were only found on Mt Kinabalu, near Panar Laban, about $1 \mathrm{~km}$ below the summit, and not at lower altitudes in this location. Huperzia australiana was mostly found growing on sandy loam soil or occasionally on sandy soil on the ridges and stream banks on the mountain, while the two other species mostly occurred in open sunny areas. 


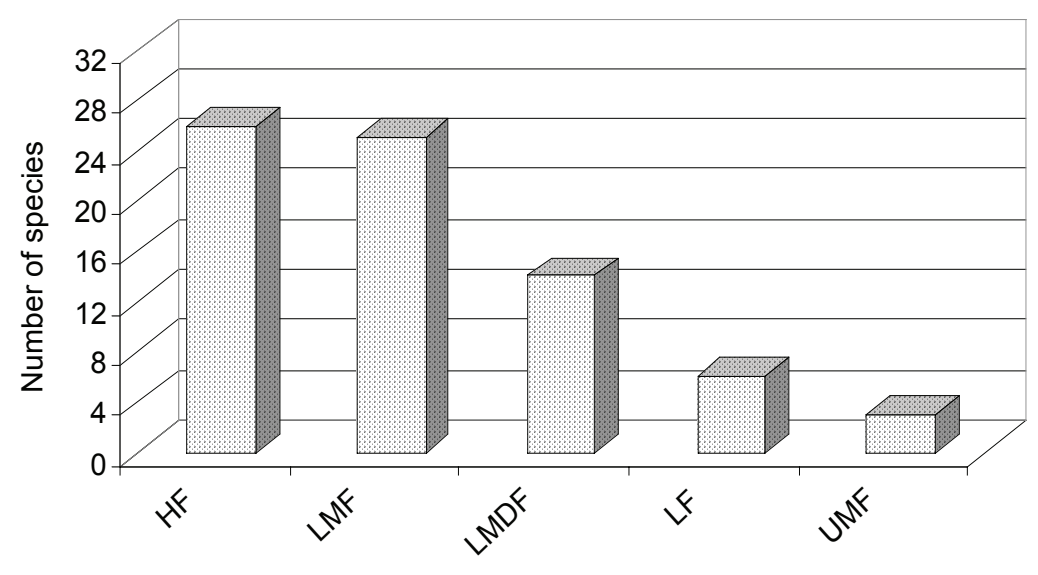

Vegetation type

Fig. 1 Diversity of Lycopodiaceae in different habitats in Malaysia.

\section{Limestone Forest}

Limestone usually occurs in the form of tower karst arising from alluvial plains and sometimes in the form of a plateau-like outcrop (Crowther 1982). Henderson (1939) divided the limestone hills in Peninsular Malaysia into three broadly circumscribed types while Anderson (1965) subdivided the limestone habitat of Sarawak into eight subdivisions. There are few collections of Lycopodiaceae from limestone forest although the area is known to harbour six different species. All species found are from the genus Huperzia and are often epiphytes or lithophytes in semi-shaded areas. The epiphytic Huperzia-species were found at about 4-6 $\mathrm{m}$ from the ground while $H$. tetrasticha usually grows about $10 \mathrm{~m}$ high on tree trunks or branches.

\section{CONCLUSIONS}

Lycopodiaceae in Malaysia are most diverse in hill forest and lower montane forest. Illegal and drastic destruction of hill forest such as in Cameron Highlands, into agricultural land may therefore have a significant negative effect on the amount of available habitat, and may lead to the disappearance of species from Malaysia. Habitat conservation and for the potentially medicinal plants, more specific protective legislation and enforcement thereof will need to be in place to safeguard these endangered and important herbs.

Acknowledgements The authors wish to thank Dr. Ruth Kiew, Dr. Saw Leng Guan (KEP), Dr. Kamarudin Mat-Salleh (UKMB), Mr. Razali Jaman (UKMB), Dr. Wong Khoon Meng (KLU), Ms. Lucy Chong (SAR), Mrs. Joan Pereira (SAN), Mrs. Rimi Repin (SNP), Ms. Serena Lee (SING) for giving permission to access and study the herbarium specimens. This study was carried out with funding from the Ministry of Science, Technology and Innovation Malaysia through IRPA 08-02-04-0025 of which the authors are very grateful for. The first author would also wish to acknowledge Flora Malesiana Foundation for partly sponsoring her to attend and present this paper at the 7th Flora Malesiana Symposium, 2007.

\section{REFERENCES}

Anderson JAR. 1965. Limestone habitat in Sarawak. Symposium on ecological research in humid tropics vegetation, Kuching, Sarawak: 49-57. Government of Sarawak, UNESCO.

Chan NW. 2001. In harmony with nature. http: //www.el.net.my/naturesociety/article13.html. Accessed on 5 March 2002.

Correll DS. 1956. Fern and fern-allies of Texas: 1-28. Texas Research Foundation, Renner, Texas.

Crowther J. 1982. Ecological observation in a tropical karst terrain, West Malaysia I. Variation in topography, soils and vegetation. Journal of Biogeography 9: 65-78.

De Winter WP, Amoroso VB (eds). 2003. Plant Resources of South-East Asia (Prosea) No. 15 (2). Cryptogams: Ferns and fern-allies. Backhuys Publishers, Leiden, The Netherlands.

Henderson MR. 1939. The flora of the limestone hills of the Malay Peninsular. Journal of the Malayan Branch of the Royal Asiatic Society 17: 13-87.

Kiew R. 1998. The seed plants flora of Fraser's Hill Peninsular Malaysia: With special reference to its conservation status: 1-27. Forest Research Institute Malaysia (FRIM), Kepong, Kuala Lumpur, Malaysia.

Øllgaard B. 1992. Neotropical Lycopodiaceae - An overview. Annals of the Missouri Botanical Garden 79: 687-717.

Parris BS. 1997. The ecology and phytogeography of Mount Kinabalu Pteridophytes. Sandakania 9: 89-102.

Wikström N, Kenrick P. 2000a. Phylogeny of epiphytic Huperzia (Lycopodiaceae): Paleotropical and neotropical clades corroborated by plastid rbcL sequences. Nordic Journal of Botany 20, 2: 165-172.

Wikström N, Kenrick P. 2000b. Relationships of Lycopodium and Lycopodiella. Resolving some of the problems using combined plastid rbcL gene and trnL intron data. Systematic Botany 25, 3: 495-510.

Wikström N. 2001. Diversification and relationship of extant homosporous Lycopods. American Fern Journal 91, 3: 150-165. 